\title{
Gender Discrimination in Building Construction Industry in Nigeria: Threat to Achieving Goal-5 of Vision 2030
}

\author{
Shirka Kassam Jwasshaka1, Nor Fadila Amin² \\ ${ }^{1}$ Department of Building and Woodwork Technology, Plateau State Polytechnic, Barkin Ladi, Nigeria \\ ${ }^{2}$ Department of Technical and Engineering Education, Universiti Teknologi, Skudai Johor Bahru, Malaysia \\ Email: cassak4real@yahoo.ca, P-fadila@utm.my
}

How to cite this paper: Jwasshaka, S.K. and Amin, N.F. (2020) Gender Discrimination in Building Construction Industry in Nigeria: Threat to Achieving Goal-5 of Vision 2030. World Journal of Engineering and Technology, 8, 33-41.

https://doi.org/10.4236/wjet.2020.81004

Received: December 12, 2019

Accepted: January 6, 2020

Published: January 9, 2020

Copyright $\odot 2020$ by author(s) and Scientific Research Publishing Inc. This work is licensed under the Creative Commons Attribution-NonCommercial International License (CC BY-NC 4.0).

http://creativecommons.org/licenses/by-nc/4.0/

\begin{abstract}
This manuscript is mainly to investigate gender discrimination in building construction industry in Nigeria. The manuscript aimed at establishing the level of women participation in building construction industry in developed nations and developing nations in order to proffer solutions for its improvement in Nigeria. It was found that the percentage of women participation in building construction work is higher among developed countries than in developing countries. In developing countries Nigeria inclusive, higher percentages of women were found to be engaged as helpers or labourers and in other unskilled jobs. It was also revealed that some of the factors affecting women participation in building construction work in Nigerian include: lack of self-confidence to compete with their male counterparts, effect of stereotyping of the profession as masculine jobs, religious believes, norms, and customs and so on.
\end{abstract}

\section{Keywords}

Attitudinal Factors, Interest, Construction Skills, Future Job Demands

\section{Introduction}

Construction industry constitutes one of the major sub-sectors that contribute to the gross domestic product (GDP) of Nigeria economy. According to [1] the sector contributes $70 \%$ of the fixed capital formation and 3\% of the GDP. Nigeria has forecast that by 2030 it hopes to gain US $\$ 257$ with an annual growth rate of $8.7 \%$ from infrastructure [2]. The construction industry is one of the sectors globally observed to be capable of contributing to the economic development of 
a nation. It is estimated that over three million people work in the industry in various capacities as professionals, administrative staff, operatives and labourers. Reports of [3] showed that the sector is one of the largest employers of labour with the approximate number of eleven million people globally. Due to culture, tradition, and religious believes, women are rarely being found in the employment of building construction work. [4] observed that most of the women found in the construction workforce are engaged in carrying out managerial, secretarial, messengers, helpers or labourers work with little or none involve in carrying out specialized and other professional work.

Nigeria has similar operation models in their construction industries with United Kingdom being their colonial masters. An observation in a report Smith Institute (2016) reveals that in the UK, the construction industry is prone to run out of staff. This scenario is already being envisaged in Nigerian construction industry because of non-involvement of women who in spite of possession of construction skills, chose to venture into other occupations such as dress making, cosmetic works, health care giver, child care homes, catering services, and other vocations abandoning their profession. [5] termed this situation as deviation rather than diversification, because it has great impact on the progress of Nigerian building construction industry.

With a large number of women populations in Nigeria, it is obvious that the economic growth of the nation will be affected if they are not accommodated in a sector such as building construction which is capable of contributing to the growth of the economy. Achieving Goal 5 of the sustainable development goals which emphasizes gender equality and empowerment of all women and girls by 2030 will be a mirage if this scenario continued.

This however, calls for an intensified global and strong advocacy to ensure that confidence is built in the women to see the need to take up construction profession in order to fight poverty and generate revenues for themselves and the society. Skill development is key in improving household productivity, employability and income earning opportunities for women. It also enhances food security and promotes environmentally sustainable rural development and livelihood [6].

There has been advocacy globally for nations to recognize gender equality as evident in the United Nations Vision 2030 document. During the general assembly of the United Nations at a millennium Summit in 2002, the whole world vowed to prioritized gender equality [7]. This resolve has not yet been felt in Nigeria construction industries as women participation is insignificant. According to [8], gender stereotyping which seems to be the primary factor of vocational dichotomy need to be tackled headlong if Nigeria desires to get it right. There has been no considerable number of women been employed in the building construction industry, hence, the necessity for the study in order to determine the reasons for this ugly trend. In Nigeria, research into women participation in building construction work is scanty and, in most cases, not empirically based as in the developed countries. However, a number of studies on the in- 
formal housing delivery a sub sector of the Nigerian construction industry have revealed that there is low level of women participation in construction.

\section{Experiences in Developed Nations}

[7] reports in his study that in the UK, from 1990 to 2005, there was stability in the percentage range of between $10 \%-12 \%$ of women employed in the built environment. Because of the busier nature of the UK construction industry during the few decades, it was experiencing skills shortage in the sector according to [9]. It is no longer news that the UK government is looking out to utilizing the talents of women and is examining ways to encourage women's entry into male-dominated jobs.

[10] reports that in the United States of America USA the speedy growing profession for women is the building construction work. Even though women only constitute about $3 \%$ of total employment in the industry, a good number of women enthusiasts are beginning to take up new enterprises in the field. Great percentage of about $30 \%$ women businesses in the building construction work has increase since 1997. The responsible factor to this is perhaps the frantic efforts made by government towards contract awards to women-owned businesses in the USA. USA government achieves this because women are treated not in equality to men but as individual in their own rights and capabilities [11]. According to Labour Statistics as cited by [12] the average employment in the European Union countries has $10 \%$ of women. In the construction industry $8 \%$ of the overall employments are women. Figure 1 shows percentage of women involvement in the building construction industries from some selected European countries.

$13.5 \%$ and $12 \%$ represents percentages from Austria and Germany respectively which is the highest percentage of active participation of women in the construction industries among the European countries. Greece records the least with 2\%, Malta and Portugal 4.3\%. Countries like Romania, UK, Netherlands, Bulgaria records between $5 \%$ to $9 \%$ of women active participation in construction sectors and France have 10\%. However, [13] observed that majority of the women who are employed in the construction industries within the European Union prefer to work as administrators, technicians and professionals rather than tradeswomen. Corroborating this assertion, [14] posits that in the UK percentage of women employed in construction sector as administrators is as high as $78 \%$.

\section{Developing Nations}

The hidden resources have remained untapped in Women among the developing nations because of socio cultural attitudes or barriers. In some African nations, for example, women are not supposed to be seen in the construction industry entirely. In Asia, the number of women outnumbers that of men in the construction industries. Productive percentages of all employee in the construction industries in Bangladesh, Thailand, and Sri Lanka, women accounts for $88 \%$ 


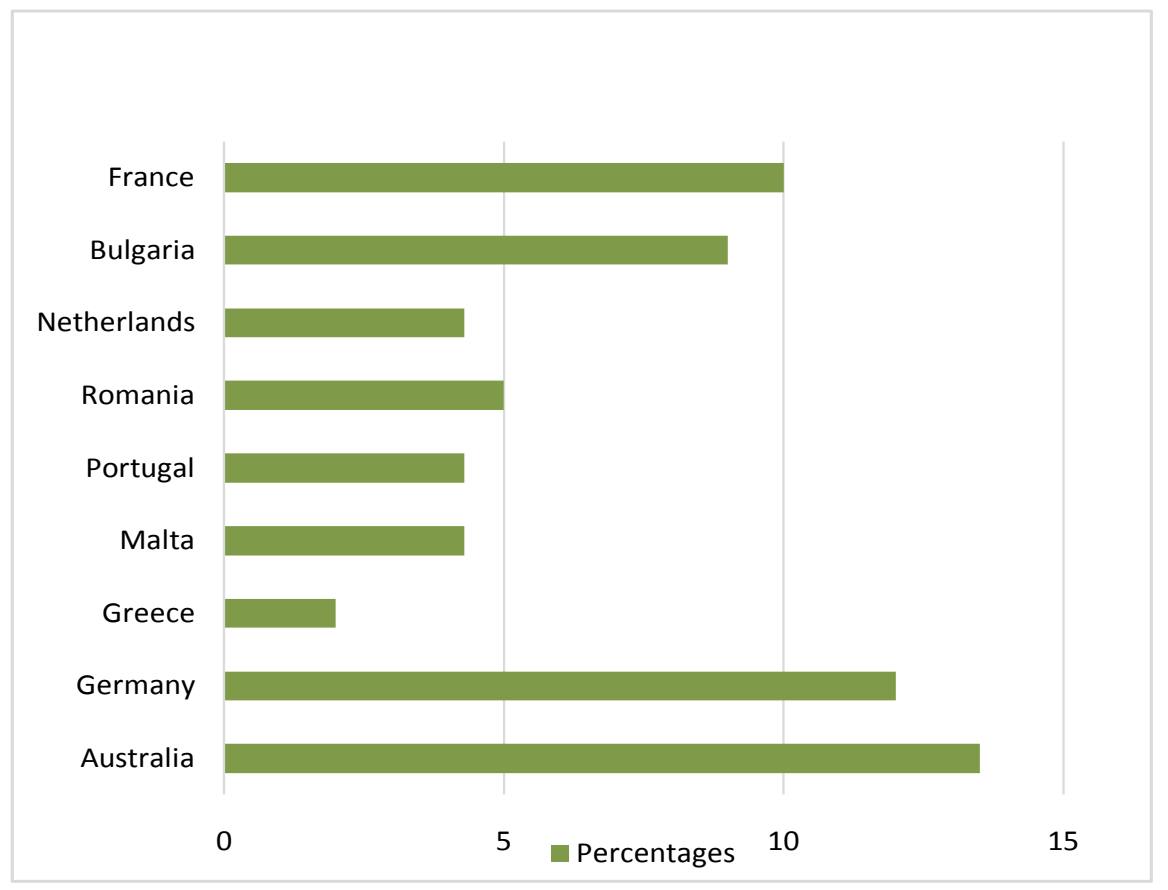

Figure 1. Women participation in construction work in some European countries, Source: Labour Statistics cited in Aulin and Jingmond (2011).

$95 \%$, and $78 \%$ respectively according to [15] the author stressed that, most of the Women employed in the construction sites in Asia are engaged as labourers or helpers and managers of building material sites, see Figure 2, where as in the Western countries, women are employed in administrative, technical and professional work. In some of these Asian countries, the place of women in the hierarchy of job is low, in fact, they are considered as people who can only do unskilled job and as head-load carriers [4]. They carry out some of the hardest and most difficult tasks and are paid less than men doing similar tasks. Sometimes, they are not paid at all and, in most cases, payment is made to their husbands (Wells 2004 cited in [4]).

In South Africa for instance, where social related jobs are occupied by $55 \%$ women, the construction industry only boast of $12.4 \%$ of all job categories because of the unpopular interest in the sector as reported by [16]. In Nigeria according to the study carried out by [1] on the percentage representation of men and women in construction industry, it was found that $50 \%$ of the women are engaged as labourers.

\subsection{Nigeria Perspective}

[17] reports that in Nigeria, the Federal Government of Nigeria increasingly views skills development as an important factor in the drive to enhance productivity, stimulate economic competitiveness, and raise people out of poverty. [18] agreed that skills and knowledge are the driving forces of economic growth and social development of any country and the economy becomes more productive, innovative, and competitive through the existence of more skilled human potential. 


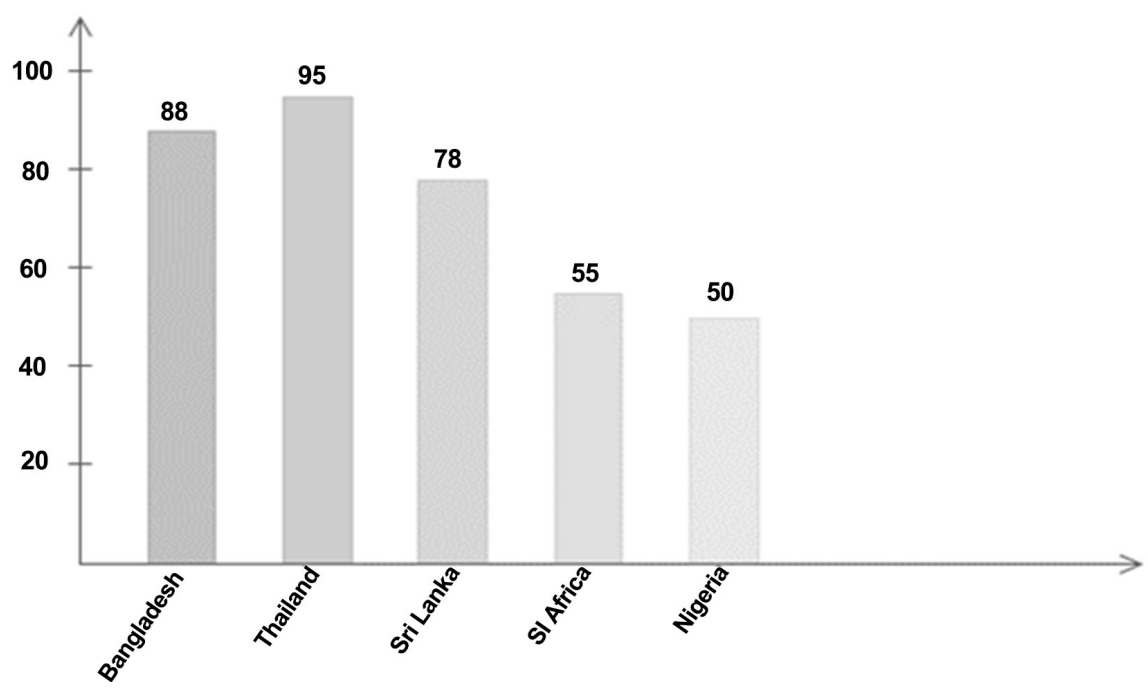

Figure 2. Percentage of Women engaged as Labourers in construction work in some developing countries. Source: Wells (2004): Statistics South Africa, (2003): Adeyemi et al. (2006).

In Nigeria the percentage representation of women that participates in one form of activities or the other is $43.1 \%$ compared to men percentage of $56.9 \%$ according to [19]. This statistical index left much to be desired because women participation has not yet been felt in the generation of revenue for the economy. [1] posits that sociocultural, ethics, and values existing among ethnics group may be responsible for the low interest of women in the construction skills in Nigeria. Some of the responsible factors as expressed by the writer comprises of "one-man-many wives" attaching more value to male child education than female under the pretext that male child is the heirs of his parents, sexual harassment, lack of self-confidence, and traditionally or religious believes. And so on.

Women have a long history of hard work and dedication in productive labour in Nigeria economy. They are industrious and enterprising; some engages in crafts work such as dying, weaving and spinning, food processing, retail trade, entertainment, and other home-based informal activities. Yet these potentials have not been maximized in the field of building construction. The economy of the country can be improved if efforts are made by the Nigerian government to harnessed these potentials in women into participating in building construction work.

\subsection{Status of Women in Building Construction Industry in Nigeria}

Women empowerment is very important as most of the proportion of the world's women population is unemployed and underemployed. They are equally competent, intelligent and talented as men and empowering them will not only benefit her individually but to the whole world at large. Women empowerment may lead to economic benefits and reduction of corruption and domestic violence which may ultimately lead to national development [6]. However, in $\mathrm{Ni}$ geria today, as opined by [20], in both industrial and academic facets of the con- 
struction industry, the rate of women's participation and enrolment is grossly low. In a report of a comparative study conducted by [1] on women and men participation in construction industries, only $16.3 \%$ of the workforces were women. The study further revealed that $50 \%$ of these women were employed as labourers, $37.5 \%$ as administrative staff, $10 \%$ as management staff and only $2.5 \%$ represents women with skill see Figure 3 below. The study concluded that women are underrepresented in the Nigeria construction industries because of their preference to administrative and other unskilled jobs to construction skills. Traditionally, Nigerian society believed that possession of construction skills is solely men's job. This societal believes is not peculiar to Nigeria alone but it cuts across the African Nations.

\subsection{Women in Vocational Occupations in Nigeria}

Women are the most vibrant and dynamic segment, as well as potentially the most valuable human resource, according to [18]. This agrees with the claims of [21] that women are better leaders, in terms of creating and articulating vision, setting clear directions, taking charge, being an inspirational model, setting high standard of performance, and assuming responsibilities. These qualities made them the dominants in the informal sector of the economy in Nigeria and very few percentages in the formal sector compared to men. In spite of their hard-working qualities, their impact is not yet felt in the construction sector. The dominant occupation saturated by women Nigeria includes catering services, small scale businesses, teaching, child care, dispensary work, orphanage home managers, rentals, interior and exterior decoration, secretarial jobs and so on. Their enrolment in construction trades in vocational schools has not been impressive too because of the societal stereotyping of construction skills as meant for men.

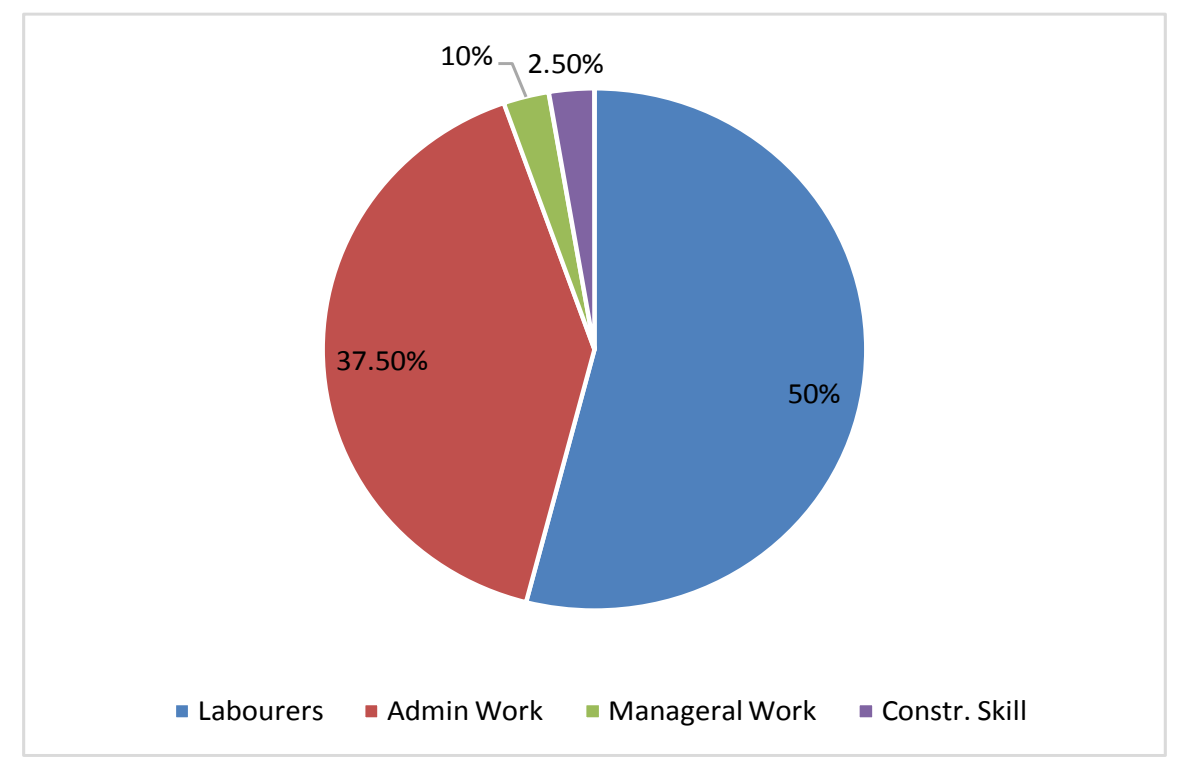

Figure 3. Women involvement in construction work according to occupation. Source: Adeyemi et al. (2006). 
The effect of lack of vocational skills is usually great on the poverty level of women according to [22]. Because of the scourge of poverty most women have taken up the challenges to equip themselves against unemployment, underemployment, in other aspect of human endeavors generally. Professional female construction workers are not left behind in empowering themselves with vocational skills within the few passed decades. [23] opined that acquisition of practical skills relating to vocation in various sectors of economic and social life will improve the standard of living of individual especially women folk who are always at the receiving end in crisis situation, and assist in eradicating poverty in the society. Personal fulfilment is the ultimate goal of professional women construction workers, who are also involved in vocational occupations. Individual who desire to prosper in their chosen career and ready to eliminate poverty should consider taking a career in any vocational skills [24] women feel satisfied when they are independent economically and so vital driving force to this is for them to acquire skills in occupation that is worthwhile such as construction.

\section{Conclusion}

From the available literature reviewed in this study, the developed and developing countries have acknowledged that building construction industry played a very vital role in the economic development of the nation. This sector contributes to a high percentage of the Gross Domestic Product (GDP) of the countries. Most of these countries' statistics showed that in spite of the benefits derivable from construction sector, the women folk have low participation. It was discovered that women have a fair representation in the developed countries such as Austria, Germany, Portugal, France, Bulgaria, and the Netherlands. In the developing nation such as Bangladesh, Thailand, South Africa, Nigeria, a high percentage of women employed in the construction sector are only engaged as labourers or helpers, Administrative staff, catering services, management and so on. The low participation was found to be attributed to a number of factors such as socio cultural, norms, values and religious factors. Globally, in spite of being dedicated, hardworking, and other qualities women folk have, they prefer to take up occupation like teaching, decoration, catering services, fashion design, childcare givers, and so on even when they have received formal training in building construction trades.

\section{Acknowledgements}

First and foremost, I wish to appreciate the benevolence of Dr. Nor Fadila Amin for her patience to put me on the right track in spite of her tight schedule as far as research is concern. The efforts of the management of Universiti Tekhnologi Malaysia, is highly commendable for providing a conducive, scholarly learning environment. I owe the authors whose journal publications were used to come up with an article worthy of publication; to contribute to the body of knowledge as this, a huge debt. I say thank you all for making your work assessable for reference purposes. 


\section{Conflicts of Interest}

The authors declare no conflicts of interest regarding the publication of this paper.

\section{References}

[1] Adeyemi, A.Y., Ojo, S.O., Aina, O.O. and Olanipekun, E.A. (2006) Empirical Evidence of Women Under-Representation in the Construction Industry in Nigeria. Women in Management Review, 21, 567-577. https://doi.org/10.1108/09649420610692516

[2] Federal Government of Nigeria (2015) Nigeria: Skills for Competitiveness and Employability: Policy Document.

[3] International Labour Organization (ILO) (2001) Tripartite Meeting on the Construction Industry in the Twenty-First Century: Its Image, Employment Prospects and Skill Requirements. Geneva.

[4] Jimoh, R.A., Oyewobi, L.O., Adamu, A.N. and Bajere, P.A. (2016) Women Professionals' Participation in the Nigerian Construction Industry: Finding Voice for the Voiceless. Organization, Technology and Management in Construction: An International Journal, 8, 1429-1436. https://doi.org/10.1515/otmcj-2016-0005

[5] Odubiyi, T.B. (2018) Nigerian Professional Female Construction Workers in Vocational Occupations: Diversification or Deviation? Organization, Technology and Management in Construction: An International Journal, 10, 1696-1703.

[6] Pitambara and Bishwa, B.C. (2017) Empowering Women through Skill Development. International Journal of Research in Humanities, Arts and Literature, 5, 27-30.

[7] Ricki, G. (2007) Women in Professional and Leadership Positions in the Construction Industry in South Africa. Unpublished MTech Dissertation, the Department of Building Sciences, Tshwane University of Technology, Pretoria.

[8] Bachelet, M. (2011) Commission on the Status of Women, 55th Session Introductory Statement. Speech Delivered on the Occasion of the Opening of the 55th of Women, 22 February, 2011.

[9] Whittock, M. (2002) Women's Experiences of Non-Traditional Employment: Is Gender Equality in This Area a Possibility? Construction Management and Economics, 20, 449-456. https://doi.org/10.1080/01446190210140197

[10] Warren, D. (2003) Construction Fastest Growing Industry for Women. Charleston Regional Business Journal, 2755-1.

[11] Schrum, L. and Geisler, S. (2003) Gender Issues and Considerations. In: Solomon, G., Allen, N.J. and Resta, P., Eds., Toward Digital Equity. Bridging the Divide in Education, Allyn Bacon, Boston, 115-128.

[12] Aulin, R. and Jingmond, M. (2011) Issues Confronting Women Participation in the Construction Industry. In: Mwakali, J. and Alinaitwe, H., Eds., Host Publication Title Missing, Makere University, Kampala, 312-318. http://lup.lub.lu.se/record/1834659

[13] Clarke, L., Pedersen, F., Michielsens, E. and Susman, B. (2005) The European Construction Social Partners: Gender Equality in Theory and Practice. European Journal of Relations, 11, 151-177. https://doi.org/10.1177/0959680105053961

[14] Michielsens, E.S. (2004) The European Construction Social Partner Gender Equality in Theory and Practice. European Journal of Relations, 11, 151-177. 
https://doi.org/10.1177/0959680105053961

[15] Wells, J. (2004) Female Participation in the Construction Industry. International Labour Office, Geneva.

[16] Statistics South Africa (2003) Labour Force Survey. Statistics South Africa, Pretoria.

[17] African Development Fund (2005) Skills Training and Vocational Education Project: Appraisal Report. Department of Social Development Centre and West Region, Nigeria.

[18] Diwakar, N. and Ahamad, T. (2015) Skills Development of Women through Vocational Training. International Message of Applied Research, 1, 79-83.

[19] Okoyeuzu, C.R., Obiamaka, P.E. and Onwumere, J.U. (2008) Shaping the Nigerian Economy: The Role of Women. Government Printer, Nigeria.

[20] Akomolafe, M.A. and Mohammed, M.A. (2014) Gender Barrier in Construction Industry. International Journal of Modern Management Sciences, 4, 1-10.

[21] Bagshaw, N. (2006) Voices from the Front Line. THISDAY.

[22] Fatimayin, F. (2013) Effectiveness of Vocational Skills Acquisition Programme on Women: Empowerment: National Open University of Nigeria as Case Study. National Oen University of Nigeria, Lagos.

[23] Ikechukwu, O. and Najimu, H. (2011) Public Private Partnership for Skill Acquisition and Vocational Technical Education Development in Nigeria. In: Proceedings of the 2011 International Conference on Teaching, Learning and Change, International Association for Teaching and Learning (IATEL), Nigeria, 755-758.

[24] Yusuff and Soyemi (2012) Achieving Sustainable Economic Development in Nigeria through Technical and Vocational Education and Training: The Missing Link. 